\title{
PERFORMANCE AND APPRAISAL FRAMEWORK FOR UNTRAINED TEACHERS WORKING IN PRIVATE SCHOOLS OF KARACHI
}

\author{
Hina Hameed Khan ${ }^{1 *}$, Abdul Karim Suhag ${ }^{2}$ \\ MS Scholar, Department of Education, SZABIST, Karachi Campus, Pakistan, email: \\ hinaqutb82@gmail.com \\ Lecturer, Department of Education, SMIU Karachi, Pakistan, email: aksuhag@smiu.edu.pk
}

\begin{abstract}
The need for performance and appraisal framework has immense importance globally and the need for the specific tool for evaluating teacher's performance which is already practised and required globally. The participants are 40 which include teachers and head teachers from both primary and secondary schooling system as well as the management staff. The selection is made on the convenience and availability of the participant to be a part of this research as respondents. The methodology for conducting data is informal discussions with the respondents and they facilitate their discussion by giving positive feedback and responses by keeping in mind the objectives of the need for research. However, the major findings of this research paper is that the number of schools does not have a proper performance tool and the teachers are unaware of the performance and appraisal criterions, whereas, these schools also do not have a proper skilled management department to keep a track of teachers' performance and appraisal records and no proper framework is developed for teachers' performance and appraisal management. Therefore, this study is reflecting the importance of performance and appraisal framework for untrained teachers working in private schools of Karachi.
\end{abstract}

Keywords: Untrained teacher, Performance management, Appraisal.

\section{INTRODUCTION}

The history of performance management_is 60 years old and it was used to determine the wages of the workers. In those days the performance management was used as a tool for reshaping the behaviour and methods associated with task performance and accomplishments. However, a great deal of justification was present between wages and performance. In 1980 the concept of performance management increased and with this understanding, the process has become more specialized and dignified (Shivali Jindal, 2015).

Performance and appraisal are always remaining the challenging task for the managers that how they can evaluate their employees to enhance their productivity and motivation which will result in the better outcomes for any organization to grow and produce its maximized benefits. Similar is in Pakistan, the performance and appraisal management is the most challenging task to encourage employee's productivity to enhance their job satisfaction at the maximum level. This study is dealing with the framework for how to evaluate untrained teachers working in the private schools of Karachi Sindh and motivate them to perform well and create interest in professional learning and development as well. However, methods of performance and appraisals 
have their strength and weaknesses. It varies from organization to organization, school to school etc. Moreover, many techniques and tools are also practised by managers for evaluating teachers' performance and appraisals which are practised globally in different other organizations. But, no specific tools or framework has been developed by these schools to evaluate teachers' performance and appraisals for untrained staff working in their institutions. Whereas, appraisals are also required to develop high-quality teaching which is very essential for the benefit of teachers and students. Therefore, teacher evaluation and appraisals should also be high in educational agendas. (Nandamuri, 2015)

\subsection{Statement of Problem}

As demonstrated by the literature review dated the need and gap are found for the proper techniques and tools or methodology to evaluate the performance and appraisal of untrained teachers teaching in private schools in Karachi. But, unfortunately, no proper or authentic techniques are present to measure teachers' performance and appraisals. Performance appraisal systems are always of imperative concern of any organization/institution while managing its human resources. Although education institutions depend upon both teaching and non-teaching staff working in it, yet major responsibility comes upon teachers who are the source of student's knowledge, learning and development. Therefore, this need for teachers' performance management compels these institutions to have systematic performance appraisal systems, in order to administer, evaluate and enhance teacher's performance. (Rashid, February 2011)

\subsection{Purpose of the Study}

The purpose of the study is to determine some core components for evaluating the performance and appraisal management tools and techniques and to develop a framework for un-trained teachers working in private schools of Karachi in a large number. The study will not only motivate them towards professional growth and development. But also justifies the reward against their efforts and hard work they put in at their workplaces.

\subsection{Research Objectives}

- To find out whether the teachers have an understanding of performance and appraisal management.

- To investigate their performance and appraisals system criterion.

- To develop a framework for the performance and appraisal managements for untrained teachers.

\subsection{Research Questions}

- What do teachers know about performance and appraisal management?

- Do you know about the criterion beforehand, how your performance and appraisal be evaluated?

- What you think of how your performance and appraisal framework should be developed?

\section{LITERATURE REVIEW}

The long-term viability and competitiveness of any organization depend on its performance management. Therefore, to evaluate the performance of employees is always a challenging task. The evaluation of performance is a valuable tool and an essential element for any management (Fekete, 2014). Evaluations are used by managers as a motivational tool to communicate their performance expectations and provide them with feedback.(Liliane. M, 2009) Stated that, "performance and competition can be evaluated by analyzing the certain performance indicators of employees' performance with well-defined measures and framework. "It further studied, that employees should have good knowledge about performance appraisal management and has a positive attitude towards their promotion and incentive increments that it will be judged honestly, with continuous feedback and suggestions from the employees too. The performance and appraisal should be made transparent and rational. (Neeti, 2015). However, the facts are to check the performance and quality properties of the employees. (Pitt, 2013). This paper reveals the performance criteria for the teachers. (Sayantani G, August 2013 ) studied the impact of performance and appraisal management related to the pay scale, role of resources, educational outcome and reliability of the existing method and created a model for performance management in India in- particular for the faculty of higher education. (Rajeev.V, 2008) In his report on performance management, he focused on establishing goals for all levels by creating KPI'S, self-reflective scorecard and providing a framework for personal development. A fundamental element is to align the personal development with the ultimate goals to achieve keep in view organizational targets. Whereas, (Jorge M. S, 2010) expressed that Performance management is the sum up of performance appraisal systems long with wider human resource systems. Furthermore, the topic depicts 
the performance and appraisal management for teachers it reveals that one of the key elements of schoolbased management is personnel policies which cover performance management. All schools should have developed a framework for performance management, such as a staff appraisal system, induction and professional development of teachers, standards, accountability tool etc. (Education and Manpower Bureau, February 2003). Performance appraisal research falls into three main groups: the first group examines the variations in student learning from teachers within the appraisal process, the second evaluates teacher perceptions of the impact of the process on their practice and levels of motivation and the third evaluates effective performance appraisal conditions (Isore, 2009).Other countries are developing many tools for teachers appraisal and performance management like in 2008. The Council of Australian Governments (COAG) agreed to a set of reforms focused on teacher quality. These reforms focused to make teaching career attractive, provide quality teacher training, appraise quality teachers, promote professional learning and support workforce mobility. (Ingvarson, 2010). However, the teacher performance should be accountable and to keep in view many Australian and other countries have developed teacher accountability with students learning outcomes. (Lawrence, 2006).Another way for measuring teacher performance appraisal through evident framework is through different test scores of the students achieved in different subjects. (Milanowsky, 2009).teacher appraisal on the other should be constructed according to the conceptual framework and should be used as a strong evident document not only to evaluate teachers. But, also serve as a guide for policymaking. (George.o.Odhiomo, 2005).Furthermore, emphasis on the failure of existing models to explain variance in pupil outcome at the classroom level, teacher self-evaluation, restricted pupil outcome, teacher's activities in and outside the classroom; curriculum subject; cross-cultural and organizational context of teaching can enhance the functional model for research and for teacher's performance and appraisal to be explored. (R. J. Campbell, 2010).Were as no specific tool or criteria is set for the assessment and evaluation of performance and appraisals but few elements can facilitate the process likewise, set performance goals, quantified levels of performance should clearly instruct, execution of plan at every level, feedback should be provided to appraiser, and system must be equipped with all legalities (Greogary D.Rankin, 1988).Moreover, the purpose of performance and appraisal management is to provide employees with feedback, management planning career development. Hence, providing employees with feedback is the primary reason for performance development (Rea, 1983). (Deoborah.F.Boiceics, 1997) That performance and appraisal management motivates employees to create a dynamic workforce. Teacher performance appraisal policies are a part of a global complex of accountability based on constructive teacher policies (Larsen, Oct 2009).Another paper indicates some problem related to the problems faced by schools and education sector for performance and appraisal management are mismanagement, the problem arises by applicants and evaluators which resulted as a major constraint for devaluation in education. (Teacher Performance Appraisal in Thailand, 2005).Looking into the teacher performance and appraisal management in 21 century is all about the knowledge of technology integration into teaching practices. (Kimberly.A.Lawless, 2007).In addition to this, a meta-analysis was conducted to evaluate teachers performance and appraisal related to the best modestly found test scores for measuring teaching competencies and performance in the preparation programs and use to significantly use the test scores for better Predictor of teaching skills. (Jerome.V'.Dagistano, 2009) - Performance appraisalll is a discrete, formal, organizationally sanctioned event, usually not performing frequently than once or twice a year, which has clearly stated performance criterion that is used in the evaluation process. We find that teachers are more productive during the school year when they are being evaluated, but even more productive in the years after evaluation. (Tyler, 2012)Moreover, rewards and awards should be given to the individual for motivation and recognition (Fatima, 2016).

\section{RESEARCH METHODOLOGY AND METHODS}

The research methodology is qualitative and the method used is grounded theory because there is no specific tool or framework for performance and Appraisal for untrained teachers.

\subsection{Population \& Sampling}

The total populations are from teachers, head teachers and administration staff from different schools located in different areas of Karachi possessing Masters and Bachelor's degree in a different discipline with working experience of minimum five years teaching in the same institution. Whereas, the sample is 40 including all the untrained teachers, head teachers and admin staff. Moreover, the selection of the participants is through personal knowledge and convenient sampling technique. All the participants are females from a different family and educational backgrounds aged from 24 to 50 years both married and unmarried teaching from grade 1 to grade 8 .and possessing 5 years or more as teaching working experience in private schools of Karachi. However, our respondents have a minimum of 5 years of working experience in the same private school they are working presently. 


\subsection{Data Collection}

The collection of data was through one to one interviews, written answers, focused group and general discussions the information was collected informally so that none of the respondents felt judged embarrassed. However, throughout the collection of data clarity of questions were made to get in-depth knowledge from the respondents, keeping in mind to construct an easily practised and understandable framework for untrained teachers working in private schools of Karachi.

\subsection{Data Analysis}

The interviews, observation and written answers were constantly monitoring and firstly the data was analyzed with open coding and after going through all the data collection again a systematic impressive thematic analysis has been constructed to create an authentic a meaningful data which will be used as major terminologies for the constructive framework to evaluate untrained teacher working in Karachi in better way.

\subsubsection{Performance Management Framework}

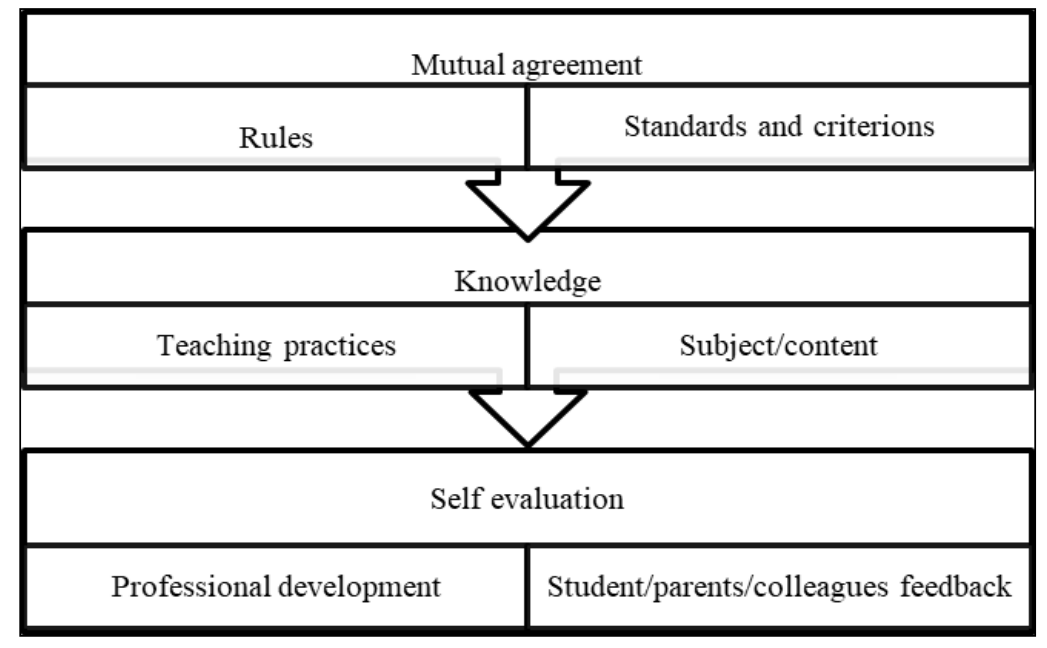

"Fig. 3.3.1"

\subsubsection{The Appraisals Framework}

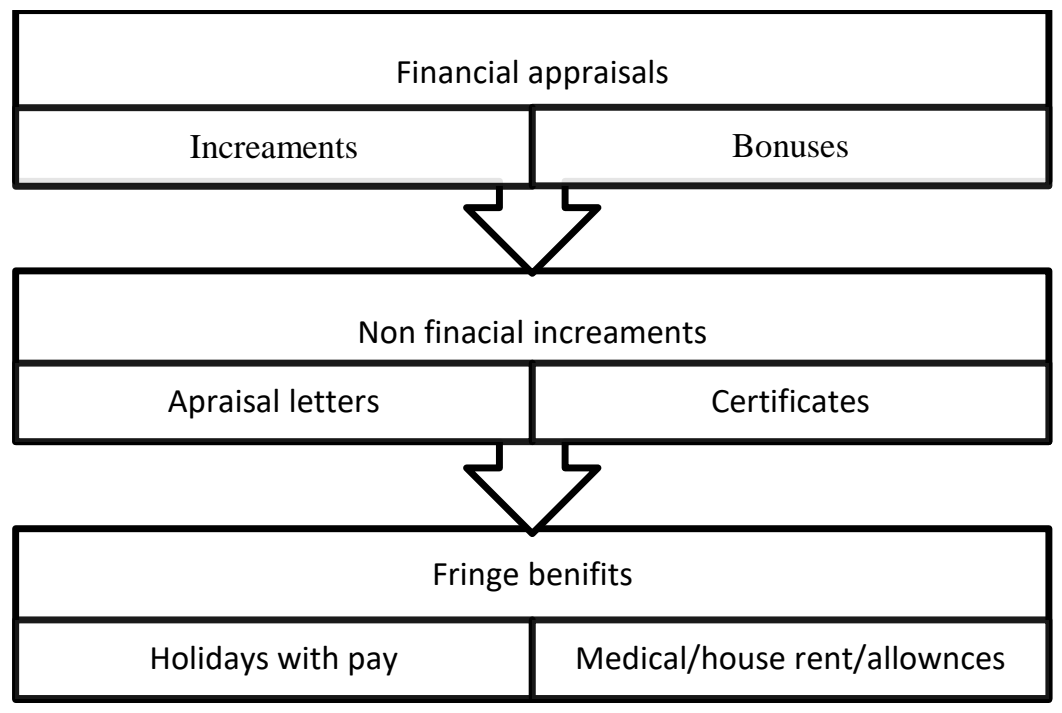

"Fig. 3.3.2"

\section{RESULTS}

\subsection{Discussion}

The performance and appraisal management is needed for better performance but unfortunately, the private schools working in Karachi are not having reliable or authentic such tools because of miscellaneous reasons. 
However, following criterion can be kept in mind which are the responsibility of our respondents to provide any school organization with a better and easy framework without hurting any employee untrained teacher.

\section{- Mutual Agreed Criterion}

The school management should be made its performance and appraisal framework with great honesty, unbiased attitude,professionalism in mind, transparency and by keeping in mind the capabilities and abilities of their teachers. It should be easy to understand and agreeable by all the members of the organization or school. The parameters should be set mutually for instance that proficiency of language,appearance, dressing of the teacher, her empathetic level towards her colleagues and students ,How well she worked in a team and quick she is in completing her task etc.all should be framed in a manner which displays transparency and no favouritism.where as a checklist can be developed to evaluate the teachers in the above-mentioned criterions.

\section{- Content Knowledge and Teaching Practices}

Sometimes the untrained teacher has more strong knowledge, pedagogies, strategies, methodologies and organizing abilities that even the degree holder trained teachers do not possess. So, the framework should be constructed in such a manner that it evaluate each teacher with having her performance in-depth knowledge, the judgements and appraisals decisions should not be made on personal choices. But according to the set parameters like How regular is she coming to her work? How is her content or subject knowledge which she is teaching? How committed is she with her work? What are her strengths while working with classroom management and her weak points? How did she deal with each of her students?Whats her way of teaching? Is she adopting traditional way or bringing innovations in her classroom? is she focused? is she task oriented? Does she like to challenge herself and want to bring a positive behaviour change in her students? The above are some under consideration points

\section{- Self Reflection/Self Evaluation}

This is missing in Karachi private school educational system. The relation with one inner self, as for how good I am as a teacher? Do I am meeting my management, students, colleagues and parents expectations? What are my strengths? what are my weaknesses? Where should I focus to perform better? How can I achieve better results? Are my content knowledge and practising appropriates according to my students need? Do I am meeting my students need? What is the best part I enjoy my work? Do I feel bored why? Talking to one self-evaluating to oneself not only improve the performance at work but, also change the attitude of oneself and give them some amazing energy and motivation intrinsically. Continuous selfreflective writings and practices or counselling sessions can help teachers to achieve their job satisfaction and zest for doing better than before can be developed.

\section{- Professional Development}

This is the core element for teaching practices as all the participants were agreed that we should be evaluated on a number of professional development training,seminars, workshops and lectures we are attending in a year. How much change in our methodology and strategies has come what fruitful result our organization or institute has achieved from each training should be evaluated and assessed as many teachers responded that these professional development courses are more expensive than our incentives or they are time-consuming or why we do pieces of training when we will not get any incentive or appraisal. So, a proper framework with proper professional development plan cannot only motivate teachers to invest in their learning but will also inspire others to work professionally. where I would like to quote the one respondent statement "invest in yourself to be cashed later"

\section{- Feedback}

Feedback is the most important tool for anything. The best manager is one which provides his employees with continuous feedback. The teacher performance and appraisals should also possess great feedback not only from colleagues, management but also from parents and students its not only motivate the teachers to work better but it also increases their self worth .this can be possible through lesson observations, checklist, written or verbal parents and student feedback and through the classroom observations and students assessment reports.

\subsubsection{Appraisal Management}

No one is this world live without appraisals, the proper appraisal framework should also be developed in the schools. According to the participant teachers they never get justified appraisals, the annual increment in salaries are the same for everyone or divided according to grade level. According to them ever teacher 
IJAEDU- International E-Journal of Advances in Education, Vol. V, Issue 13, April, 2019

needs a proper appraisal and justifications. The disparity in appraisals not only made them dishearted, irritated, sad, frustrated But also burnt -out and they don't feel like working with high spirits and does not able to prove themselves at their fullest (PITT, 2013).

\section{- Financial Appraisal}

These appraisals are highly liked by every participant.According to the yearly salary, increments should be given on the performance criteria and every individual should be assessed on a specifically agreed framework.Secondly, some other financial incentives like bonuses, holiday packages, professional development opportunities, festival gifts etc cannot only increased the performance of the teachers But also motivate them to work with more dedication and honesty.

\section{- $\quad$ Fringe Benefits}

Fringe benefits are another type of appraisals indicated by participants and according to them its also motivated them to perform well. But according to one of the participants they are not justified as, many schools give freeships to the teachers children but what about those who are also working at their fullest but not married? Maternity leave with pay is given and plus the 40 days leave also given in some institutions again it's not justified with everyone.In this manner, some of the employees are getting higher appraisals if their benefits also add up. Whereas, the other gain minimal increments in their salaries. A transparent appraisal framework should be developed to benefit the teachers according to their performance management criterions whether in terms of benefits as medical, house rent,holiday packages, club memberships or education compensations etc or in shape of annual increments in their salary packages Hence,.this will create equal opportunities for every employee working in that private school.

\section{- Non-Financial Appraisals}

This study emphasises on the non-financial appraisals as well like after continuous feedback a nice written appraisal letter or certificates can do miracles in the performance of the teachers they not only give them a sense of achievement But also encourage them to work more harder and motivate them to work at their maximum potentials. Hence according to the teacher respondents, they felt happy and attain maximum job satisfaction with these type of appraisals.

\subsection{Findings}

Teaching in private schools in Karachi is always taken as a half day job and has been taken as "anyone who has studied can teach." According to general opinion, no proper training is required for teaching. On the other hand, the school owners appointed teachers with the only prominent qualification as fluent in the second language as the most important trait in a "TEACHER" and secondly, her appearance. During, my data collection, I observed and find out that there are no proper criteria for teachers' recruitment or teachers' performance and appraisal management in a number of private schools working in Karachi. However, this is also observed that most of the teachers' teaching in these schools do not possess any certificate or professional teaching degree like B.Ed. etc. Furthermore, they are practising the old methodology of teaching and a rotting system is a common practice in these schools. There is no special criteria prevailed for measuring teacher performance and appraisals and whereas, yearly increments also has no proper justification or criteria for an increase in salary for the particular teacher, No proper framework or tool for assessing teacher performance is established in these schools which results in demotivated, uninterested ,lazy teachers on one hand and on other hand, the teachers who are intrinsically motivated feel depressed and sometimes burnt-out. Moreover, the head teachers and office staff are also not trained and equipped with the knowledge to monitor the teacher performance and appraisal management with transparency and without bias attitudes. According to the head teachers, and management there is a number of the management claim because of transitory teachers in the organization the framework cannot be developed.Furthermore, they claim that new teachers in the organization are always appointed on the higher pay scale so, to bring harmony in scales would be a difficult task. Whereas, they also proposed that teachers who join this profession are not loyal and dedicated to this profession. Untrained management staff is also a hurdle in creating and assessing teacher performance and appraisals. Politics in the staff will be developed as everyone will think that the appraisals are done on the personal preferences of the management. The mindset of the employers that old teachers have more loyalty for the institutions and they are the pillar of the institution so we cannot deprive them, No matter if they are not performing according to the current needs of the organization. Fear of teacher will quit the institution if she will be given professional development. Hence, it also stated by the participants that school management is short of finances to hire a proper data analyst.Furthermore, it also stated that no document has been provided to the institutions from the government education department regarding how many appraisals a teacher should get and criterion. 
Therefore, the framework has been developed from this study to help these schools in establishing a proper tool to assess and evaluate their teachers and benefitted them with their job satisfaction and to help management and head teachers to develop their need-based inexpensive performance and appraisal management tool.

\subsection{Recommendations}

The institutes should develop a proper framework or implement the above framework which not only increased the productivity of the teachers but also create a love for their work in themselves. A good organization or institute will never deprive their workforce rather they will encourage and motivate each member of the organization to perform with all the efforts they can put in. So, the performance and management should be taken as a golden key to success for any institute to delicately evaluate the strengths and weaknesses of their teaching staff with continuous feedback and appraisals to create a team which can do wonders and bring about positive change in the field of education.

\section{REFERENCE LIST}

1. Teacher Performance Appraisal in Thailand. ( 2005). Educational Research for Policy and Practice, 115-127.

2. Chand, s. (n.d.). Performance Appraisal Methods: Traditional and Modern Methods (with example).

3. Deoborah.F.Boiceics, B. (1997). Designing effective performance appraisal systems. International Journal of productivity and performance management, 197-201.

4. Elliott, K. (2015). Teacher Performance Appraisal: More about Performance or. Australian Journal of Teacher Education, 102-116.

5. Fatima, S. A. (2016). Teachers Insight about Performance Appraisal System and Its Inferences on Their Commitment and Skills of Job at Secondary Level. Journal of Socialomics.

6. (February 2003). Education and Manpower Bureau. manpower bureau.

7. Fekete, M. (2014). The practical model of employees performance. Human capital without border management (pp. 141-149). portorz solivinia: MAKE LEARN.

8. George.o.Odhiomo. (2005). Teacher appraisal: the experiences of Kenyan secondary school teachers. Journal of education administration, 402-416.

9. Greogary D.Rankin, B. S. (1988). Effective performance appraisal. Industrial Management \& Data Systems, 13-17.

10. Ingvarson, L. (2010). Recognising Accomplished Teachers in Australia: Where have We been? Where are We Heading? Australian Journal of education (ACER), 46-71.

11. Isore, M. (2009). Teacher evaluation: Current practices in OECD countries and a literature OECD education working paper. $t$. Organisation for Economic Cooperation and Development.

12. Jerome.V'.Dagistano, S. (2009). Predicting Teacher Performance With Test Scores and Grade Point Average: A Meta-Analysis. American Educational Research Journal, 146-182.

13. Jindal, S., \& Laveena. (2015). Study of effectiveness of performance appraisal. International journal of research granthaalyah, 2394-3629.

14. Jorge M. S, C. F. (2010). Directions for Future Research, Rio D Janeiro,A Literature Review of Maintenance Performance Measurement. 1-15.

15. Kimberly.A.Lawless, J. (2007). Professional Development in Integrating Technology Into Teaching and Learning: Knowns, Unknowns, and Ways to Pursue Better Questions and Answers. SAGE journals, 575-614.

16. Larsen, M. A. (Oct 2009). Stressful, Hectic, Daunting: A Critical Policy Study of the Ontario Teacher Performance Appraisal System. Canadian Journal of Educational Administration and Policy, 1-44.

17. Lawrence, E. H. (2006). Teacher accountability in Australia: current policies and practices and their relation to the improvement of teaching and learning. Research Paper In Education, 31-49.

18. Liliane. M, P. M. (2009). Empirical Analysis of Maintenance Performance. International Journal Of Production Research, 5901-5920. 
19. Milanowsky, A. ( 2009). The Relationship Between Teacher Performance Evaluation Scores and Student Achievement: Evidence From Cincinnati. Peabody Journal Of Education, 33-53.

20. Nandamuri, D. P. (2015). An Appraisal of the Teacher Appraisal System. Avenshek, 5.

21. Neeti, S. (2015). Study of performance appraisal system and it's effectiveness in the FMCG industry. International Journal of Research \& Development in Technology and Management Science-Kailash, Volume - 22, 53-63.

22. Pitt, M. (2013). In research in Malysia. Eksploatacja i Niezawodność, 111-116.

23. PITT, M. (2013). In research in Malysia. Eksploatacja i Niezawodność, 111-116.

24. R. J. Campbell, L. K. ( 2010). Differential Teacher Effectiveness: Towards a model for research and teacher appraisal. Journal of Oxford Review Of Education, 347-362.

25. Rajeev.V. (2008). Research report:: Indian FMCG Industry by Action financial services India Ltd.(AFSIL).

26. Rashid, M. I. (February 2011). A critical analysis of the performance appraisal system for teachers in public sector universities of Pakistan: A case study of the Islamia University of Bahawalpur (IUB). African journal of business management, 3735-3744.

27. Rea, R. (1983). practitioner Forum Effective performance appraisal. Journal Of Accountancy, 112.

28. Sayantani G, N... (August 2013 ). New Model of Performance Management and Measurement in the Higher Education Sector. International Journal Of scientific Research Volume: 2, 267-274.

29. Shivali Jindal, L. N. (2015). Study of effectiveness of performance appraisal. international journal of Granthaalya, 2394-3629.

30. Tyler, E. S. (2012). The Effect of Evaluation on Teacher Performance. American Economic Review, 3628-3651. 